\title{
MULTIPLE ERFARINGER I MULTIPLE SETTINGER \\ - MEMUS, et teoretisk rammeverk for museumsformidling
}

\author{
Merethe Froyland
}

Museer som laringsarena er et tema mange er opptatt av. Flere har forsøkt à beskrive hva som kjennetegner museene som et sted hvor laring kan skje, og de har bidratt fra ulike ståsted. George Hein oppsummerte 1998 hvordan museer kan leve opp til leringssynet konstruktivismen. Falk og Dierking har 1992 og 2000 presentert "The Contextual Model of Learning", som beskriver museumsbesøket som samspill mellom personlig, sosial og fysisk kontekst. Crane og hans medarbeidere diskuterer 1994 hvordan museer som uformelle laringsmiljø skiller seg fra formelle laringsmiljø, og etterspør samarbeid mellom disse. Alle disse har med utgangspunkt $i$ undersøkelser som er gjennomfort $i$ museer rundt $i$ hele verden forsøkt à si noe om hvilke konsekvenser funnene fär for museumsformidlingen. De har sarlig satt fokus på hvor det er behov for mer forskning. Jeg ønsker derimot her å sette fokus på museumspedagogens hverdag. Dette kan ses på som et redskap for dem som ønsker at laring skal skje i museene, en teori for praktisk handling, og som jeg kaller MEMUS (Multiple Erfaringer i Multiple Settinger).

Den praksis som vil bli anbefalt gjennom MEMUS har læring som mål. Og med læring mener jeg ikke den type kunnskap som "huskes", men den type kunnskap som "forstås". Med forståelse mener jeg det samme som Howard Gardner (1999a): [at] ...et individ forstår et begrep, en ferdighet, en teori, et kunn- skapsomrade $i$ den grad at han eller hun kan overføre dette på en hensiktsmessig måte til en ny situasjon. Dette synet er sammenfallende med det Ausubel et al. (1978) beskriver som meningsfull læring og som innebærer at ny informasjon, det kan være fakta, holdninger og følelser, er linket til eksisterende infor- 
52 masjon i den lærendes kunnskapsstruktur på en slik måte at den lærende er i stand til å erindre denne informasjonen etter en tid, og til å overføre disse ideene til ny situasjon og problem.

Et slikt mål innebærer at man ser på læring som en prosess over lengre tid som det er påpekt av flere ${ }^{1}$. Det er ikke gitt at et enkelt museumsbesøk kan gi denne type læring, men besøket kan være et ledd i en prosess fram til forståelse hos individet.

Det vil her bli framsatt et rammeverk for å hjelpe museumspedagoger å skape museumsopplevelser som

- bygger på en forståelse av at læring er en aktiv prosess $i$ individet og at hvert individ har sin egen tilnærmingsmåte - multiple erfaringer - forutsetter at læring skjer over tid - multiple settinger.

Rammeverket, MEMUS, fokuserer på at museene bør tilby de besøkende multiple erfaringer. Museene bør presentere informasjonen på ulike måter slik at den blir tilgjengelig for flest mulig. I tillegg fokuseres det på at museene bør tilpasse og utnytte at deres tilbud er et av flere tilbud fra ulike læringsmiljø og settinger.

\section{Multiple erfaringer PA MUSEet GIR INDIVIDUELL LÆRING}

Howard Gardners (1993a, 1999b) teori om multiple intelligenser (MI-teorien) kan fungere som et bra rammeverk for å gi individuell læring gjennom bruk av multiple erfaringer. Her vil jeg argumentere for hvorfor jeg mener det, og komme inn på hvordan jeg mener museene kan bruke MI-teorien.

To sentrale retninger har dominert forskning på læring. Den ene retningen forsøker å forstå hva som skjer i hodet på individet. Her har Jean Piaget ${ }^{2}$ lagt et viktig grunnlag som har resultert $i$ at man er blitt klar over at læring er en aktiv prosess som individet selv styrer. Den andre retningen fokuserer på det sosiale og de kulturelle forhold rundt individet når læring skjer, her har russeren Lev Vygotsky ${ }^{3}$ vært sentral. Denne retningen har gjort oss oppmerksomme på at læring skjer i kontakt med andre mennesker og blir preget av den kulturen man er vokst opp i.

Etter Piaget og Vygotsky begynte man å bli opptatt av det faglige innholdet, hva elevene fikk med seg av det som ble undervist, noe som ga skremmende resultater. Flere elever beholdt sine dagligdagse forståelse på tross av at de var blitt undervist naturvitenskaps forståelser. ${ }^{4}$

Det kom fram hvor sterk barnets intuitive forståelse av verden rundt det var, og at dette var en utfordring for undervisningen. Ausubel (1968) uttrykte dette på denne måten "Dersom jeg må redusere all undervisnings psykologi til kun et prinsipp, vil jeg si dette: Finn ut hva den larende kan fra for og undervis han deretter." Han påpeker hvor viktig det er for læreren å få tak i elevens førkunnskaper. Med andre ord har alder mindre å si, det er det du kan eller ikke kan som bør være avgjørende for hvor man starter formidlingen.

Førkunnskapene og de mulige hverdagsforestillingene skoleundervisning kan skape ble viktige utgangspunkt innenfor det konstruktiviske læringssynet. Derfor ble også samspillet, den sosiale sammenhengen, mellom de som lærer og mellom den lærende og læreren viktig. Samtidig hadde Piaget gjort det klart at individet selv er konstruktør av egen læring, noe konstruktivistene også støtter. Derfor kan man si at konstruktivismen har hentet elementer fra Piaget og de "individsentrerte" og fra Vygotsky og de "sosiokulturelt" sentrerte. 
Mange har kritisert konstruktivismen, blant annet fordi den sier så lite om hva miljøet rundt kan gjøre for å stimulere læring hos eleven. ${ }^{6}$ Osborne sier at konstruktivistene forveksler læring med "å gjøre" ("hans on") og at aktiviteter for så vidt er bra, men det bør diskuteres hvilke typer aktiviteter som fremmer læring. Osborne og Rice (1998) mener at det er på tide å se på "minds on" ikke bare "hands on", det bør settes mer fokus på de aktiviteter som fremmer refleksjon og forståelse hos den lærende. Her mener jeg konstruktivismen har mye å hente fra teorien om multiple intelligenser (Gardner 1993a, 1999b).

\section{Multiple intelligenser \\ - MULTIPLE ERFARINGER}

Howard Gardner har framsatt en teori (Multiple Intelligenser, MI) om at vi mennesker har et medfødt biopsykologisk potensiale som består av flere likestilte intelligenser. Hittil har Gardner identifisert 8 intelligenser:

- Språklig intelligens - følsomhet for lyd, struktur, mening og funksjon av ord og språk.

- Logisk-matematisk intelligens - følsomhet for og evne til å skille logiske og numeriske mønstre, evne til å behandle lange resonnementskjeder.

- Visuell-romlig intelligens - evne til å oppfatte den visuelt romlige verden nøyaktig.

- Musikalsk intelligens - evne til å produsere og verdsette rytmer, tonehøyder og klangfarger.

- Kroppslig-kinestetisk intelligens - evne til å kontrollere kroppens bevegelser og håndtere objekter.

- Naturalistisk intelligens - evne til å gjenkjenne og klassifisere objekter både fra flora og fauna.

- Interpersonlig intelligens - (sosial) evne til å forstå og reagere adekvat på stemning, temperament, motivasjon og ønsker til andre mennesker.

- Intrapersonlig intelligens - tilgang til egne følelser og evne til å skille mellom følelser. Kunnskap om egen styrke og svakhet.

Dette medfødte potensialet utvikles i en sosial og kulturell sammenheng. Han definerer intelligens som følgende:

Et biopsykologisk potensiale til å behandle informasjon som kan bli aktivert i en kulturell setting til å løse problemer eller utvikle produkter som er verdifulle for en kultur.

Kulturen setter dermed både stengsler og skaper muligheter for individuell utvikling. Gardner gir flere eksempler på hvordan ulike kulturer "dyrker fram" ulike egenskaper. For eksempel favoriserer ugandere langsomt og grundig engasjement i aktiviteter, mens meksikanere legger vekt på mellommenneskelig følsomhet og kinesere verdsetter mestring av store mengder faktisk informasjon. Den enkelte er ikke født dyktig, men utvikler kompetanse gjennom læretid. Det er bare på noen få områder at den enkelte kan utvikle ekspertise bare ved å lese.

\section{Kriteriene FOR INTELligensene}

For å komme fram til nettopp disse 8 intelligensene har Gardner brukt klart definerte kriterier med støtte fra flere fag. For, som han sier, nevrologien viser at intelligensene har en bestemt plassering i hjernen, biologien gir rammer for naturlig menneskelig intelligens, men kulturelle forhold vil farge måten potensialet utvikles. Kort oppsummert stiller han seg flere spørsmål for å identifisere en intelligens:

- Er det aktivitet på et bestemt område i hjernen når denne evnen stimuleres? 
54 - Finnes det spor av intelligensen hos andre arter, og tidligere samfunn?

- Finnes det et sett med operasjoner og et symbolsystem som kjennetegner intelligensen?

- Finnes det spesielle personer - genier/autister - som demonstrerer intelligensen særlig?

- Støtter IQ tester og eksperimentell psykologi at intelligensene ikke er korrelerte/henger sammen med hverandre?

\section{BRUKEN AV MI-TEORIEN}

Teorien er etter min mening et utmerket rammeverk for å tenke og planlegge multiple erfaringer innenfor alle mulige læringssituasjoner. Gardner mener at utdannelse skal sørge for grunnforståelse av våre ulike verdener - den fysiske verden, biologiske verden, verden for menneskeheten, verden av menneskelige objekter og verden til selvet. Videre sier han at basisferdigheter som lesning, skriving og telling, bør sees på som middel og ikke mål i seg selv.

Skolen og andre læringsmiljø har konsentrert seg om de to første intelligensene; språklig og logisk-matematisk, mens Gardner mener at alle intelligensene bør være likeverdige og ha samme prioritet.

Som små barn lærer vi intuitivt, da er det samfunnets oppgave å legge til rette for at barna har tilgang til aktiviteter som stimulerer alle intelligensene. Det er i denne aldersgruppen utvikling av de fleste intelligenser skjer og det er derfor viktig å gi barna mulighet til å utvikle og utvide sitt potensiale. Gardner mener at vitensentre og barnemuseer er gode eksempler på slike læringsmiljø for førskolebarn.

I mellomskolealder er det viktig å lede barna inn i vår kulturelle verden og vår forståelse av verden rundt oss. Her foreslår han lærling- ordning som en god metode, der mesteren forteller og demonstrerer for svennen. Eksperter viser hvordan faget kan håndteres og veileder barnet ved å lære det symbolspråket.

I videregående alder er det viktig å fokusere på ungdommens evner og produkter, stimulere dem til selvstendig arbeid, egen refleksjon og egne produkter. Ungdommenes produkter bør stå i sentrum, de skal ikke kopiere faste bilder, men bruke kreativiteten og produsere noe selv. De skal ikke lenger bare gjenta etter mesteren, men selv begynne å bli mestere.

\section{DISKUSJON RUNDT TEORIEN MULTIPLE INTELLIGENSER}

Det har vært framført noe kritikk på MI-teorien. Noen er uenige i bruken av begrepet intelligenser og andre kritiserer at Gardner ikke har noen beviser for sin teori, at den består av en samling tankerekker. ${ }^{7}$ Denne kritikken bør likevel ikke hindre museumspedagoger å gi publikum et variert og mer tilpasset museumstilbud, som tar hensyn til ulike tilnærmingsmåter og som ikke favoriserer noen framfor andre.

Faren er når MI-teorien blir brukt til å plassere barn og voksne i bås akkurat som IQ-tester har vært brukt til. Gardners teori inneholder bare noen flere båser å velge mellom. Man kan tenke seg at et barn som får høre hvor velutviklet det er innen kroppslig-kinestetisk intelligens, kan bli hindret i å utvikle andre intelligenser fordi det selv skaper sperrer, eller miljøet rundt legger bare til rette for den ene intelligensen. På den måten kan MI-teorien bidra til et ensporet syn på barn og voksnes evner. En slik ensporing kan være ødeleggende for barna, og en skremmende utvikling for samfunnet.

Dette er misbruk av MI-teorien. Gardners 
visjon er å finne hvert individs sterke sider og ikke stemple noen som svake. Han mener vi skal ta utgangspunkt i de sterke sidene og bruke det som bro til de områder individet ikke er så sterk på. På den måten vil hver enkelt oppleve at han/hun lykkes i noe, og vedkommende blir også gitt noen utfordringer. Visjonen er ikke å skape et samfunn som er ute etter å dømme hvem som er flink og hvem som er svak, men et samfunn som gir rom for, setter pris på og likestiller ulike evner.

Thomas Armstrong (1998), en kollega av Gardner, har satt opp følgende fire punkter som er viktige å huske på i forhold til MI-teorien:

1. Alle mennesker besitter alle åtte intelligenser. MI-teorien er ikke en "type-teori” for å kategorisere etter intelligenser. Det er en teori om kognitiv funksjonsdyktighet. Det blir presisert at alle mennesker har evner innen alle åtte intelligenser, og at de arbeider sammen på en måte som er unik for hvert enkelt menneske.

2. De fleste mennesker kan utvikle hver intelligens til et fyllestgjørende kompetansenivå. Gardner mener at stort sett alle har kapasitet til å utvikle alle intelligensene til et rimelig høyt funksjonsnivå, hvis man får passe oppmuntring, betingelser og undervisning.

3. Intelligensene fungerer vanligvis sammen på en kompleks måte. Gardner påpeker at hver av intelligensene som han har beskrevet faktisk er fiktive. Det betyr at ingen intelligenser forekommer isolert (bortsett fra i meget sjeldne tilfeller, som hos hjerneskadede o.l.).

4. Det er mange måter å være intelligent på innen for hver intelligenskategori. Det er ikke noe standardsett av grunnleggende egenskaper som man skal ha for å bli betraktet som intelligent innenfor et spesialområdet. Det betyr at en person som har problem med å lese godt kan være språklig begavet fordi han er en fantastisk historieforteller eller har stort ordforråd. MI-teorien påpeker det rike mangfoldet av måter folk viser sine talenter innen intelligensene, såvel som mellom dem.

Multiple intelligens teorien beskriver hvert individ med 8 ulike typer intelligenser eller 8 ulike måter å innhente informasjon på, som arbeider sammen på en måte som er unik for hvert enkelt individ. En praktisk konsekvens av teorien for museene er å gi publikum multiple erfaringer, noe jeg skal diskutere senere.

\section{MI-TEORIEN OG FELLESTREKKENE Med KOnstruktivismen, Piaget OG VYGOTSKY}

Howard Gardner er enig med Piaget at vi er født med et potensiale og en egen driv til å lære. Men han fokuserer også sterkt på kulturens påvirkning og framdrift av denne utviklingen. Det synes derfor som om læringssynet til Gardner har fellestrekk med både Piaget, Vygotsky og det konstruktivistiske læringssynet; vi er gitt et potensiale, noen indre muligheter, som i sosialt og kulturelt samspill utvikles.

Med sin stadieteori mente Piaget (Inhelder \& Piaget 1958) at han presenterte en teori for intelligensens utvikling. Gardner mener at Piaget beskriver utvikling av kun én intelligens blant flere; den logisk-matematiske.

Vygotsky mente at alle høyere mentale funksjoner har sosial opprinnelse og først eksisterer mellom individer (på et interpersonlig plan) før de blir internalisert $\mathrm{i}$ individet (på et intrapsykisk plan). ${ }^{8}$ Språket binder det interpersonlige og intrapsykiske plan sammen, og har to funksjoner: det brukes til å betrakte sosial interaksjon mellom individene og kognitiv aktivitet $\mathrm{i}$ individet. ${ }^{9}$ Her er han inne på 
flere av Gardners intelligenser som intra- og interpersonlige intelligenser og den språklige intelligensen. Vygotsky synes å sette den språklige over de to andre fordi han mener denne er bindeleddet, mens Gardner likestiller dem.

Videre mente Vygotsky at barn kan ikke bli kjent med seg selv uten gjennom å kjenne andre, mens Piaget mente barnet først må bli kjent med seg selv i en egosentrisk fase, før det forstår andre. Gardner (1993b) mener at begge er inne på noe viktig. De beskriver bare ulike sider ved utviklingen av barnets personlige intelligenser, den intra- og interpersonlige intelligens.

Samspillet mellom ekspert og elev som Vygotsky framhever som viktig, er i tråd med Gardners syn på lærlingordningen (Gardner 1993b).

Med andre ord: Gardners MI-teori inneholder deler fra Piaget, Vygotsky og konstruktivismen. I tillegg rommer MI-teorien flere perspektiver som de andre teoriene ikke rommer, og som jeg opplever veldig konstruktive når den skal omformes til praksis. Teorien gir ingen fasit, men den fungerer som et rammeverk for læringens ulike fasetter og er et meget godt grunnlag for å tenke og planlegge formidling. Kort fortalt kan den hjelpe museumsformidlere til å gi publikum multiple erfaringer, som inkluderer sosialt samspill, fysisk og mental erfaring med gjenstander og oppdagelse av gjenstandenes utallige sider; dens historier, dens anvendelse, dens estetikk, dens lydbilde osv. La oss se litt nærmere på anvendelsen av Gardners teori i museene. Hva vil dette si for museene i praksis?

\section{Anvendelse AV MI-teori \\ I MUSEENE}

Gardner (1999a) er ikke alene om å foreslå at museene bør gi publikum ulike erfaringer. Hedge (1995) presiserer at det er viktig at utstillingene ikke er like og forutsigelige, da mister folk interessen. Andre, som Falk og Dierking (2000), oppfordrer museene til å variere tilbudet, og Miles og Tout (1994) presiserer at dette er viktig for å hindre museumstretthet. Perry (1994) konkluderer med at utstillinger bør pirre nysgjerrigheten, gi de besøkende selvsikkerhet, utfordre dem, la besøkende oppleve at de har kontroll, og invitere til lek og kommunikasjon - med andre ord gi variert tilbud,

Nedenfor diskuterer jeg en del aktiviteter og formidlingsmetoder som museumspedagoger kan bruke for å gi publikum multiple erfaringer. Aktivitetene og metodene er sortert etter hvilke intelligenser jeg mener de stimulerer, og deres kvaliteter blir vurdert med støtte fra funn samlet gjennom flere museumsundersøkelser.

\section{SPRÅKLIG TILNÆRMINGSMÅTE}

"Besøkende leser ikke museumstekster" er blitt en sannhet blant museumsansatte. Noen går så langt som å la være å bruke tekst $i$ utstillingene. Vi skal her se at dette er ikke så enkelt. Faktisk er det noen som leser tekst og noen av dem ganske mye også. Om tekstene blir lest eller ikke er avhengig av mange forhold: tekstens form og innhold, hvem de besøkende er, hvordan de tilegner seg informasjon og hvem de kommer sammen med.

Museumstekster, forelesninger, lydopptak og dialogene eller samtalene er de virkemidlene museene har for å stimulere den språklige intelligensen. Dialogen og samtalene vil bli tatt 
opp under delkapittelet "sosial eller interpersonlig", mens vi her skal ta for oss museumsteksten. La oss se litt nærmere på hvem som leser eller ikke leser museumstekster og hvorfor.

\section{Formålet med teksten}

Formålet med teksten er viktig. Screven (1995) har satt opp 5 punkter for hvilke funksjoner museumstekster har:

1. De gir informasjon om det de besøkende ser: Navn, datoer, hvorfor objektet er med i utstillingen, hva det brukes til.

2. De gir instruksjoner til de besøkende om hva de skal gjøre, merke seg eller se etter

3. De gjør temaene personlige og trekker linjer fra det nye og ukjente til kjente erfaringer.

4. De tolkerinnholdet i utstillingen - sanseinntrykkene, betydningen, årsakene, virkningene. 5. De orienterer de besøkende om hva de kan vente seg av utstillingen, hvordan den er organisert og hvordan de kan forholde seg til innholdet $\mathrm{i}$ utstillingen.

Besøkende føler behov for å være orientert og vil gjerne vite hva de går til. Gode orienteringer om utstillingens innhold, hvor lang tid det tar å se utstillingene etc. gjør de besøkende fornøyd og øker deres kunnskap. ${ }^{10}$

\section{Hvem de besøkende kommer sammen med}

Hvem de besøkende kommer sammen med er avgjørende for om de leser tekstene. I grupper hvor det er barn, for eksempel i familiegrupper, blir tekster sjelden lest (McManus 1999). Selv ikke instruksjoner til en aktivitet blir lest. Det er stort sett bare når familiemedlemmene ikke får til en aktivitet at de til slutt leser instruksjonsteksten (Diamond 1986). Par eller enkeltbesøkende, leser veldig mye tekst, derimot diskuterer de den lite (McManus 1999).
Inviterer teksten til a bli lest?

Teksten må invitere til å bli lest. For eksempel går det an å iverksette tiltak for å få flere til å lese tekstene. Bruk av spørsmål har vist seg å fungere både inspirerende og pirrende. I et forsøk formulerte Hirschi \& Screven (1999) noen spørsmål som besøkende kunne finne svar på i de øvrige tekstene. Det hjalp, flere begynte å lese tekstene etter dette. Åpne spørsmål fører til at besøkende bruker utstillingene mer kreativt (Eratuuli \& Sneider 1990). Det er også vist at bruk av pc i utstillingene stimulerer besøkende til å lese museumstekster. ${ }^{11}$ Tekstens form er et annet virkemiddel. Blais (1995) og McLean (1993) gir mange gode råd om hva som er optimal lengde på en utstillingstekst, hva slags ord og formuleringer man bør unngå, hvilken skrifttype og -størrelse som er gunstig og hva man bør huske på ved plassering av tekstplakater (f.eks. lesehøyde og lyssetting).

\section{Valg av tekstens innhold}

Tekstens innhold er også avgjørende for om folk leser den, og hva de får ut av den. Tekster kan engasjere, inspirere og provosere alt etter hvilket innhold man velger å presentere. $\mathrm{Mu}$ seer har lenge vært opptatt av at informasjonen skal være nøytral, som nevnt innledningsvis. Coxall (1999) viser hvordan tekster ikke er nøytrale men alltid et resultat av holdninger og valg av innhold, og at dette er viktig å være klar over for museumsansatte. I følge Kentley \& Negus (1999) bør tekstene være klare, konsise, relevante, konsistente og entusiastiske. De oppfordrer også til å være direkte i tekstene, fortelle besøkende hva de skal se etter i stedet for bare å informere dem hva de kan se. De mener også at spørsmål kan øke læringsutbyttet og redusere de besøkendes tretthet. Humor kan være bra, men bør bru- 
58 kes med omhu. Videre har de forslag om hvordan informasjonen bør struktureres.

Dersom tekstene inneholder vanskelige vitenskapelige ideer og prinsipper, kan korte tekster være skadelig for forståelsen (Davidson 1984). Disse krever lengre setninger (Shuy \& Larkin 1978).

Bruk av historier gir også utbytte. Kognitive undersøkelser viser at folk mentalt kan organisere informasjon effektivt dersom den er presentert for dem ved hjelp av historier. ${ }^{12}$ Det er også funnet at folk lager historier for seg selv om sine erfaringer, og at historiene hjelper dem til å gi mening til erfaringene. ${ }^{13}$

\section{Noen gode virkemidler}

- Fortelle gjenstandens mange historier

- Gi gode orienteringer om innholdet på museet både skriftlig og muntlig (guide).

- Bruke spørsmål

- Invitere til samtale

- Bruke lydsett hvor innholdet er presentert på kassett

- Bruke historier, ordsketsjer, dikt etc.

- Bruke pc, multimedia

- Tilby foredrag

- Ta i bruk hukommelsesspill

\section{LOGISK-MATEMATISK TILNÆRMINGSMÅTE}

Museer kan være med å stimulere den logiske og matematiske tilnærmingsmåten gjennom eksperimenter eller interaktive utstillinger. Slike utstillinger inviterer de besøkende til å forutsi eller utlede en hypotese om hva som vil skje dersom de gjør en bestemt handling, og gir de besøkende mulighet til å teste sin hypotese. Utstillinger som tar i bruk informasjon med tall som størrelser, antall prosent etc, eller som er framstilt gjennom grafer, tabeller eller diagrammer er også tilrettelagt for logisk matematisk tilnærmingsmåte.

Det viser seg at interaktive utstillinger holder lengre på barn og unge enn statiske og mer tradisjonelle utstillinger. ${ }^{14}$ Ikke alle interaktive utstillinger fungerer bra. Det er viktig at aktivitetene inviterer til engasjement, at de besøkende bruker litt tid på aktiviteten og at de besøkende må tenke over hva som skjer og hvorfor. ${ }^{15}$ I tillegge til hands on har man inkludert minds on som viktige aspekt i utvikling av aktiviteter (Osborne 1998).

For å holde på publikum og få dem til å gjøre aktivitetene viser det seg i noen forsøk at bruk av tekst på riktig måte, kan øke eksperimenteringen. ${ }^{16}$ Under "Kroppslig og kinestetisk" er interaktive utstillinger diskutert nærmere.

\section{Noen gode virkemidler}

- Presentere gjenstandens tall (som størrelse, vekt, antall), og knytt den til hypoteser

- Illustrere informasjon gjennom statistikk, tall, grafer og tabeller

- Stimulere til problemløsning

- Bruke praktiske eksperimenter

- Invitere til hypotesetesting, analyse og tolkning av data

- Bruke matematikkoppgaver og matematikkspill

\section{ROMLIG/VISUELL TILNÆRMINGSMÅTE}

Det visuelle er viktig for læring hos alle, men appellerer særlig til dem som lett tilegner seg informasjon visuelt. En utstilling og et utstillingslokale er veldig visuelt, derfor kan man si at museene med sine utstillinger virkelig bidrar til å gi de besøkende visuelle erfaringer. Men ikke alle er like vellykket. Vi skal her ta for oss hvordan museet bør hjelpe de besøken- 
de til å orientere seg fysisk på museet og i de enkelte utstillingene, hvordan den fysiske konteksten og design og struktur av utstilling er viktige for læringsutbyttet hos den besøkende.

\section{Orientering i rommet}

Hiemstra (1993) skiller mellom feltavhengige og feltuavhengige museumsbesøkende. De feltuavhengige behøver ikke hjelp til å forstå en utstilling, de bygger opp egen struktur og får med seg det utstilleren hadde tenkt, mens andre er mer feltavhengige og behøver klart definert struktur og hjelp til å lære det som formidles.

Besøkende er mer fornøyd når de får vite hvor de ulike fasiliteter og utstillinger finnes ${ }^{17}$, og i følge Levine (1982) er et oversiktskart plassert strategisk for besøkende svært viktig. Dette kartet bør, i følge ham, inneholde blant annet et "her står du nå" - merke og "landmerker", det vil si utstillinger eller deler av utstillinger som er synlige fra der de står og leser. Publikum foretrekker å få kart som de kan ta med seg rundt i utstillingene (Bitgood \& Richardson 1987), og da bør de være så enkle som mulig med noen lett gjenkjennelige landmerker avmerket.

Voksne og barn orienterer seg ulikt. Dersom barn er $\mathrm{i}$ et avgrenset rom som hindrer dem i å se resten av utstillingen eller museet, konsentrerer de seg bedre om den utstillingen de er ved. For voksne kan manglende oversikt være ødeleggende for museumsopplevelsen (Frank 1992).

Førstegangs besøkende oppfører seg annerledes enn hyppig besøkende (Falk \& Dierking 1992). De førstegangs besøkende bruker mer tid på å orientere seg og finne veien, mens mer museumsvante kjenner til reglene for hvordan man oppfører seg på museet og kan derfor konsentrere seg om utstillingene. Dette gjelder for voksne som for barn. Dersom man har en skoleklasse på besøk, bør barna få tid til å akklimatiseres, det vil si bli kjent med det fysiske rommet på museet, før undervisningsprogram starter, ellers har barna problem med å konsentrere seg (Balling \& Falk 1980).

Det er gjort en del undersøkelser på hvordan folk beveger seg rundt i utstillingene. Her er listet opp noen momenter:

- Folk går fra landemerke til landemerke (Bitgood 1999). Et landemerke kan være lyd, bevegelige objekter og store objekter.

- Når de kommer inn i et utstillingslokale, starter de ved den nærmeste utstillingen (Bitgood 1999).

- Utstillinger som er plassert midt i rommet kan ofte bli "lommer" som ingen besøker. ${ }^{18}$

- De besøkende velger oftere utstillinger der det er andre besøkende til stede, dersom det ikke er for mange eller kø (Bitgood 1999).

- Folk velger ofte korteste vei gjennom utstillingen til utgangsdøra (Melton 1935).

- Utstillinger ute i periferien blir sjelden sett (Bitgood og Richardson 1987).

- Folk har en tendens til å gå rett fram om mulig (Bitgood 1999), og svinge til høyre (Melton 1935) dersom ikke noe annet trekker $\mathrm{i}$ andre retninger.

\section{Innhold $i$ relevant kontekst}

Det viser seg at evnen til å omgjøre erfaringer til fornuftige og meningsfulle kunnskaper for individet, ja faktisk evnen til å lære, er sterkt avhengig av individets evne til å sette tidligere erfaringer inn i den konteksten erfaringene hører til. ${ }^{19}$

Hvis barn og voksne har blitt presentert for et begrep i et dekontekstualisert fysisk miljø, kan de ha problem med å lære materialet i første omgang, og ikke minst ha vanskelig for å 
60 overføre informasjonen til en ny situasjon (Falk $\&$ Dierking 2000). Læring er bare generaliserbar til nye situasjoner dersom individet kjenner igjen elementer i den ukjente læringskonteksten fra en kontekst da tidligere læring skjedde (Perkins \& Salomon 1989).

Flere og flere psykologer har oppdaget eksempler på individer som gjennomfører oppgaver dårlig i laboratoriet, mens de gjør det veldig bra når det gjennomføres i en meningsfull fysisk setting eller kontekst. ${ }^{20}$

\section{Design og struktur}

Det fysiske rommet er avgjørende for hvordan objekter, ideer og besøkende møtes og omformes (McLean 1993). Bruk av farge kan påvirke folk følelsesmessig (Belcher 1991). Tekstur og mønster kan også framkalle følelser. Veldig store eller små gjenstander kan fungere tiltrekkende på publikum. Bra design kan skape et rammeverk som oppmuntrer den besøkende til å studere et objekt og lese teksten (Falk \& Dierking 2000).

Det er ikke alltid de veldig strukturerte utstillingene som oppnår størst suksess. En faglig sett ustrukturert utstilling, som gir de besøkende mulighet til selv å velge hvilke elementer de vil bruke tid på, oppnår like stort læringsutbytte som utstillingen hvor det faglige innholdet følger en strukturert rekkefølge der publikum må følge designeres rekkefølge (Falk 1999).

$\AA$ plassere et objekt i en utstilling hvor det egentlig ikke hører hjemme, kan vekke oppmerksomhet hos voksne, mens barn ikke engang legger merke til det (Frank 1992). Bruk av video kan også øke de besøkendes kunnskapsutbytte. ${ }^{21}$

\section{Noen gode virkemidler}

- Få fram gjenstandens estetikk eller mangel på det, dens form og farge

- Bruke bilder, symboler, diagrammer

- Gjøre orienteringen i rommet enkel gjennom kart etc.

- Tenke gjennom bruk av design, lys og farge - Bruke aktiviteter (inkludert pc-programmer) som puslespill, orientering i rom, knyttet til arkitektur

- Bruke tegneserier eller symboler i stedet for tekst

- Bruke film og video

\section{KROPPSLIG KINESTETISK TILNÆRMINGSMÅTE}

Det er mange som lærer gjennom å bruke hendene og kroppen. Det er gjennom bruk av sansene og kroppen vi mennesker innhenter vårt første erfaringsgrunnlag som mye av vår videre kunnskap bygger på. Noen av oss videreutvikler dette og blir svært dyktige med hendene og kroppen. Utstillinger med aktiviteter og gjenstander som de besøkende kan ta på og bruke til noe ("hands on" aktiviteter) er derfor viktige for disse besøkende. Vi kaller slike utstillinger interaktive utstillinger, og de viser seg å være effektive som formidlingsform. ${ }^{22}$

Interaktive utstillinger tiltrekker seg flere besøkende og holder lengre på dem, enn statiske utstillinger, og kan dermed også bidra til bedre læringsutbytte. ${ }^{23}$ Det har vært dokumentert langtids læringseffekt etter interaktiv utstilling (Stevenson 1992). For at interaktive utstillinger skal oppleves morsomme og gi læring, er instruksjonene viktige. Og for at instruksjonene skal bli lest bør de være klare, enkle og synlige (Eratuuli \& Sneider 1990). 
Ikke alle er like aktive brukere av interaktive utstillinger. Barn bruker "hands-on" oftere enn voksne. ${ }^{24}$ Men her finnes det unntak, for eksempel leker grupper med eldre entusiastisk med interaktive utstillinger selv uten barn (Donawa 1999), og kvinner som besøker museer alene leker oftere med interaktive utstillinger enn menn som besøker museene alene (McManus 1999).

Det å erfare gjenstander påvirker holdninger (Hedge 1995). Et eksperiment gjort av Fazio et al. (1978) skilte mellom direkte og indirekte erfaringer. Direkte erfaringer kan være å leke med en dokke, mens indirekte kan være at et barn blir fortalt om en dukke av et annet barn. CD-rom, video, bøker etc. gir indirekte erfaringer, mens museene gjennom "hands on" kan gi direkte erfaringer. Fazio et al. (1978) fant at direkte erfaringer gir affektive resultater og påvirker oppførselen til de besøkende i større grad sammenlignet med indirekte erfaringer. Det kognitive utbyttet, det å huske informasjon, var derimot uavhengig av om erfaringene var indirekte eller direkte.

Bruk av teater (Hughes 1993) og drama (Hayes \& Schindler 1994) er en annen måte å bruke kroppen på og kan gjøre innholdet mer tilgjengelig for besøkende. Bruk av instruksjoner som "Tenk deg at du er en geolog" og som blir gitt de besøkende i det de skal besøke en utstilling, viser seg å kunne gi positiv effekt på læring. ${ }^{25}$ Det samme gjelder "late som"-lek, som fremmer både kognitiv og sosial utvikling. ${ }^{26}$

Bruk av pc og dataprogrammer inviterer også publikum til å være aktive. Serrell og Raphling (1999) har utredet hva designere av et dataprogram bør ta hensyn til dersom de ønsker at dataprogrammet skal bli tatt i bruk og nå fram til de besøkende i utstillingen. Fle- re undersøkelser ${ }^{27}$ viser at presentasjoner gjennom pc øker læringsutbyttet hos de besøkende.

\section{Noen gode virkemidler}

- La publikum ta på, lage eller bruke gjenstanden

- Bruke dans, rollespill, drama, teater

- Involvere besøkende i dans, rollespill og drama

- Bruke praktiske eksperimenter med håndverk, modeller og ekte gjenstander

- Anbefale eller arrangere ekskursjoner eller turer som er relevante

- Bruke pc og dataprogrammer

\section{MUSIKALSK TILNÆRMINGSMÅTE}

Lyd og musikk er noe museene etterhvert har tatt $\mathrm{i}$ bruk i utstillingene. Det finnes lite informasjon om hvordan dette virker på publikum, men noen få undersøkelser finnes det. Peart (1984) viste at lyd tiltrekker publikums oppmerksomhet. Ogden et al. (1993) viste i et forsøk med og uten lyd i en utstilling, at bruk av lyd kan gi både kognitivt og affektivt utbytte. Det kan virke som om museene ikke har eksperimentert så mye med bruken av musikk og lyd, så her finnes det et utviklingspotensiale.

\section{Noen gode virkemidler}

- La publikum erfare gjenstandens lyd eller lydbilde

- Bruke lydbilder eller lydkulisser (fuglesang, gregoriansk sang, lyden av en maskin som er i gang)

- Invitere besøkende til å lage lyd gjennom musikkinstrument, sang og ulike gjenstander

- Bruke relevant musikk 
62 - Bruke musikal, eventuelt invitere publikum til å delta

\section{Naturalistisk TILNÆRMINGSMÅTE}

Museumssamlingene er et resultat av flere menneskers evne til å samle og sortere levende og ikkelevende materiale etter likheter og ulikheter og se sammenhenger mellom dem. Dette er også noe museene i større grad burde utfordre de besøkende til. Nettopp med museumssamlinger som utgangspunkt har museene utmerkede muligheter for å stimulere den naturalistiske intelligensen.

De tradisjonelle utstillinger viser mengder av gjenstander og er egentlig et bilde på det museumssamlingene representerer. Men som vi har vist tidligere har ikke de tradisjonelle utstillingene særlig appell til publikum. Museene må derfor teste ut nye måter å stimulere den naturalistiske tilnærmingsmåten.

Noen museer har begynt å åpne magasinene for publikum, andre har utviklet et system slik at besøkende kan bruke utstillingene og de ansatte til å få identifisert objekter de selv har kjøpt, fått eller funnet. Dette er en begynnelse, men her har museene et stort utviklingspotensiale.

\section{Noen gode virkemidler}

- La publikum bli kjent med gjenstandenes systematikk

- Invitere besøkende inn i museumssamlinger

- Invitere publikum til å få identifisert sine gjenstander

- Tilby aktiviteter rundt systematikk, for eksempel kurs i registrering av samlingene

- Tilby aktiviteter rundt taxidermi, for eksemple kurs i utstopping av dyr

- Tilby aktiviteter med sortering av gjenstander, gjenkjenning av likheter og forskjeller etc.
INTERPERSONLIG (= SOSIAL FORSTÅELSE) TILNÆRMINGSMÅTE

Flere $^{28}$ har framhevet museenes utmerkete mulighet til å stimulere sosial læring, fordi de besøkende ofte kommer sammen i sosiale grupper og fordi det ofte er plass til flere rundt samme utstilling samtidig. Det er ikke bare av praktiske årsaker at man oppfordrer museene til å stimulere det sosiale samspillet, men også fordi det viser seg at sosial interaksjon tillater besøkende å gå lengre enn deres egen individuelle erfaring, og utvider deres kunnskap og deres måte å lære på. ${ }^{29}$ De fleste undersøkelser som tar for seg sosialt samspill har sett på familiegrupper, men flere av disse funnene har overføringsverdi til andre grupper.

Det meste av det vi lærer, har vi lært gjennom barndommen ikkeverbalt fra foreldre, nære slektninger og venner, mener Bandura \& Walters (1963). Derfor, sier de, er "modellæring", sosiallæring og observasjonslæring veldig viktig. Museene kan legge til rette for slik læring gjennom flere tiltak. De kan invitere de besøkende til sammen å løse en oppgave. Gjennom museumstekstene kan museumsansatte stille spørsmål som får de besøkende til å diskutere sammen. Ved bruk av guider og vakter kan museumsansatte selv ta kontakt med de besøkende og skape dialog mellom ansatte og besøkende.

Det har vært gjennomført en del museumsundersøkelser av hvordan samspillet mellom barn og voksne fungerer og påvirker begge parters utbytte. Eratuuli \& Sneider (1990) viste gjennom sine undersøkelser at dersom barn og voksne gjøre noe sammen øker det deres glede over læringssituasjonen og fleres forståelse innen det faglige innholdet. Crowley \& Callanan (1998) fant at de mest potente "hands on" utstillingene var de som inviterte 
barn og foreldre til samarbeid. Dierking \& Falk (1994) har laget en oppsummering av noen av funnene fra undersøkelser på familielæring: - Mødre er de som mest sjelden velger hvilken utstilling familien skal stoppe ved.

- Når mødre er alene sammen med barnet, er de mer aktive sammen med sønnen enn med datteren.

- Familier går gjennom museer på en forutsigbar måte, det vil si at det finnes en generell oppførsel i museene blant familier.

- Familiemedlemmers diskusjon og opptreden foran utstillinger tyder på at de har lært noe. Ofte knytter de informasjonen i utstillingene til kunnskaper de har fra før.

- Familielæring er avhengig av flere variabler, som: tidligere kunnskaper, type utstilling, kjønn og alder, forholdet mellom barn og foreldre og når i besøket familien når en utstilling.

- Familielæring er både kunnskaps- og opplevelsesdominert, hvor det sosiale er avgjørende.

- Det er liten evidens for at instruksjon på forhånd hjelper for læring hos barn i en familiesetting.

Borun et al. (1998) har identifisert 7 karakteristiske trekk ved familievennlige utstillinger; 1 . De bør være multisidete slik at familiemedlemmer kan stå rundt samtidig. 2. De bør være multibrukere så flere kan bruke den samtidig. 3. De bør være tilgjengelige slik at både barn og voksne lett kan bruke dem. 4. De bør gi multiresultater, det betyr at resultatene varierer og er komplekse nok til å skape en diskusjon. 5. De bør være multimodale slik at de appellerer til ulike læringsmåter og kunnskapsnivå. 6. De bør være lesbare ved at tekst er oppdelt i segmenter som er forståelige 7. De bør være relevante slik at materialet skaper lin- ker til besøkendes tidligere kunnskap og erfaring.

I en zoologisk hage i England undersøkte de hvordan samtalen var mellom voksen og barn om dyrene (Olson, 1998). De fant at den voksne ofte navngav dyret på spørsmål fra barnet og drog barnet videre til neste dyregruppe. Dette ville de ansatte gjøre noen med og utarbeidet tekster som ble hengt opp i voksen høyde. På tekstene sto det: "Dette kan du spørre barna dine om." og så var det listet opp noen spørsmål som gikk på detaljer om dyrene i området. Dette gjorde at familiemedlemmene sto lengre ved hver dyregruppe og hadde en lengre dialog om dyrene.

\section{Noen gode virkemidler}

- Bruke gjenstanden som utgangspunkt for en dialog eller sosial aktivitet

- Bruke aktiviteter og oppgaver som må løses sammen med andre

- Bruke tekst etc. som stimulerer til dialog

- Bruke spørsmål som besøkende kan stille hverandre

INTRAPERSONLIG (= SELVFORSTÅELSE) TILNÆRMINGSMÅTE

Ikke alle besøkende lærer best gjennom sosialt samvær. Noen liker best å studere på egen hånd, og museene kan være med å gi også disse besøkende et relevant og tilrettelagt tilbud. Aktuelle tiltak kan være å ta opp tema som appellerer til å tenke selv, å be publikum om å finne ut hva de mener om en sak, eller å presentere problemstillinger som ikke har et svar, men som inviterer til å kombinere kunnskap og holdninger før man kommer fram til en egen konklusjon.

Vi har også sett gjennom undersøkelser innen naturfagundervisning at læringsutbyt- 
64 tet er avhengig av hva den enkelte kan fra før og hvilke interesser den enkelt har. Dette er også bekreftet gjennom undersøkelser gjort i museene (Crane et al. 1994). Bower (1981) har også funnet at ulike utstillinger framkaller ulikt humør hos den enkelte besøkende, og dette påvirker igjen hva den besøkende husker fra museumsopplevelsen. Serrell \& Raphling (1999) påpeker at personlig engasjement øker når de besøkende kan se konsekvensene av sine valg og handlinger, noe dataprogrammer og bruk av pc i utstillinger kan bidra med.

\section{Noen gode virkemidler}

- Bruke gjenstanden og vis hva den har med den enkelte besøkende å gjøre

- Bruke spørsmål som provoserer, engasjerer og inviterer til indre refleksjon og selvforståelse

- Bruke aktiviteter som kan løses på egenhånd

- Pc og dataprogrammer som kan betjenes alene

\section{OpPSUMMERING}

Her er gitt en oppsummering av hvordan museumspedagogene kan ta på alvor at vi mennesker er forskjellige, og legge til rette for individuell læring. Men denne oppsummeringen betyr ikke at en hver utstilling, et hvert undervisningsprogram skal inneholde alle 8 elementene som er oppsummert her. Hver utstilling eller program må vurderes hver for seg. Det bør testes og sjekkes hvilke tilnærmingsmåter som er naturlig i forhold til emnet, og hvilke som når fram til publikum. Noen ganger fungerer kanskje bare to, andre ganger passer det å inkludere alle 8 tilnærmingsmåtene.

Det viktige er at museumspedagogen tenker multiple erfaringer og forsøker å presente- re temaet på flest mulig måter. Å tenke multiple erfaringer inviterer til kreativitet, man ser emnet eller faget fra vinklinger som en ikke har tenkt på tidligere. Det inviterer også til å samarbeide med andre fagpersoner som er forskjellig fra en selv, for å få hjelp til å utvikle aktiviteter tilpasset tilnærmingsmetoder som er forskjellig fra dem en selv god på.

I et undervisningsprogram vi kalte Geomusa (geologi i museum) ga vi deltakerne, som var skoleelever, multiple erfaringer gjennom aktiviteter innenfor alle 8 tilnærmingsmåter (Frøyland, 1997, 1998). Geomusa er en modul innenfor det vi kaller "Extended Classroom Model" (ECM, det utvidete klasserom modellen). Ideene med denne modellen er at museer i samarbeid med skole skal gi elever multiple erfaringer i multiple settinger. $\mathrm{Vi}$ fant at Geomusa ga elevene både kognitivt og affektivt utbytte. Det var særlig de begrepene som ble demonstrert gjennom flere aktiviteter og satt inn i ulike kontekster som virkelig ble forstått av elevene. Da vi spurte elevene hva de likte best, fikk vi ulike svar. Til sammen nevnte elevene aktiviteter innenfor alle tilnærmingsmåtene vi hadde valgt å bruke i Geomusa. Det bare bekrefter at elevene er forskjellige og at vår formidling bør ta hensyn til dette.

Oppsummert er det flere fordeler med å inkludere multiple erfaringer i museumsformidlingen:

- Formidlingen er tilpasset flest mulig individer og deres tilnærmingsmetoder.

- Faget eller emnet blir presentert fra ulike vinklinger og treffer derfor flere besøkendes interesser.

- Formidlingen blir variert og ikke forutsigelig.

- Fordi formidlingen varierer, vil de fleste oppleve at de mestrer noen aktiviteter ganske lett mens andre kanskje er mer utfordrende. 
- Utfordrer museumspedagogen til å presentere faget eller emnet gjennom ulike aktiviteter og stimulerer derfor dennes kreativitet.

\section{"Multiple settinger" TAR Hensyn TIL TID OG KONTEKST}

Flere har påpekt at læring ofte skjer over tid..$^{30}$ Læring kan være en langvarig prosess noe som for eksempel en museumspedagog må ta hensyn til. Det betyr at når museumsformidlere planlegger sin formidling er det viktig å ha klart for seg at museumstilbudet er en liten bit av en mye større sammenheng. Det samme påpeker Falk \& Dierking (2000), de sier at det er viktig at ansatte på museene planlegger undervisningsprogram, utstillinger og nettsider som deler av en større læringsarena for de besøkende, og ikke som om museumstilbudet var $i$ et vakuum uavhengige av verden rundt.

I praksis kan det bety at museumspedagogene må forsøke å følge opp de tema som blir tatt opp i andre miljø eller settinger som bibliotek, arkiv, bøker, tidsskrift, TV-programmer, radio-programmer, pc-programmer, internett eller aviser. På den måten får publikum presentert kunnskap over tid, og museumspedagogen har tatt hensyn til at læring er langvarig.

Når kunnskap presenteres gjennom ulike medier eller settinger, vil den også samtidig bli satt inn i ulike kontekster, presentert fra ulike vinklinger og dermed gir publikum et nyansert bilde av kunnskapen.

Laring som prosess og kunnskap $i$ kontekst ligger i det som jeg har valgt å kalle "multiple settinger"-perspektiv på formidlingen.
HVorfor ER "MUltiple SETtinger" VIKTIG?

For at et demokratisk samfunn skal kunne fungere økonomisk, forvalte sine ressurser fornuftig og ha en befolkning som er i stand til å leve gode liv, må befolkningen være allmenndannet. Det betyr at befolkningen bør ha et visst kunnskapsnivå innen flere fag, være i stand til å reflektere rundt kunnskapen og ta den i bruk i sitt daglige liv - de må ha lært og forstått kunnskapen.

Skolen spiller en svært viktig rolle i denne sammenhengen. Den er med på å gi elevene et viktig grunnlag. Gjennom 10 års (eller mer) undervisning blir også tidsperspektivet tatt med i elevenes læring, men flere undersøkelser viser at skolen ikke alltid lykkes. Det er mange som går ut av skolen og mangler basal kunnskap innen for eksempel naturfagene (Driver et al. 1994). Årsakene kan være at elevene ikke får undervisning som gir multiple erfaringer (Gardner 1993b), og at kunnskapen ofte er løsrevet fra relevant kontekst. ${ }^{31}$ Skolen har behov for å forbedre sin undervisning, gjennom blant annet samarbeid med andre læringsarenaer.

Dessuten er det ingen, eller få, som går på skole hele livet. Hva da med all den nyervervede kunnskapen som produseres etter at man er ferdig på skolen? Hvordan sørger vi for at de som er ferdig med skolen stadig blir oppdatert?

Her er det mange miljø som kan spille en viktig rolle, som nevnt tidligere; bøker, tidsskrifter, TV-programmer, internett og ikke minst museer. Vi snakker her om flere læringsmiljø eller multiple settinger, som har et felles mål om å opplyse en befolkning. For å oppnå dette målet er man avhengig av at befolkningen forstår og virkelig lærer det som blir formidlet. 
HVILKEN KONSEKVENS FÅR "MULTIPLE SETTINGER" FOR MUSEUMSFORMIDLINGEN?

Læring tar tid. Det sier seg selv at et enkelt museumsbesøk gir de besøkende et begrenset læringsutbytte selv om museet tar i bruk multiple erfaringer, med mindre museet har utstillinger eller lignende tilbud som tar opp emner den besøkende har hørt om før, slik at museets budskap kan kobles til noe som allerede er kjent. De besøkende kan ha lest eller hørt om det samme emnet i andre museer eller ander settinger (TV, Internett, aviser etc), og dermed har de noe å bygge informasjonen fra museet på, og sjansen for at de lærer øker.

Det betyr at museumspedagogene må være orientert om hva som skjer i samfunnet, hvilke emner blir tatt opp i andre settinger, og forsøke å følge opp de emnene som er naturlige for deres museum å følge opp. Først da er det håp om at de besøkende lærer noe og museet gir sitt bidrag til å skape et samfunn med en allmenndannet befolkning.

Hvordan er status i dag på norske museer når det gjelder å ta opp aktuelle emner? Opplever publikum museene som informasjonskilder som bidrar til allmenndannelsen? I en undersøkelse (Henriksen \& Frøyland 2000) fant vi at ingen av våre intervjuobjekter oppfattet museer som informasjonskilde. Deres assosiasjoner til museer var "gammeldags, statisk, historie etc". Det var særlig dette med at museene var litt tilbaketrukket i forhold til tiden og samfunnet rundt, som intervjuobjektene assosierte med museene. Publikum oppfatter ikke museene som relevante i forhold til deres daglige liv.

Museenes ansatte har tydeligvis ikke vært gode nok til å sette museumstilbudet inn i en sammenheng med det samfunnet det tilhører.
Derfor etterlyser myndighetene i Norge større satsning på emner som angår samtiden i de norske museene, som miljøvern og det flerkulturelle (Kulturdepartementet 1996).

Museer i andre land har kommet lengre på dette feltet og de har mye å lære de norske museene. Eksempler er science sentre eller vitensentre som vi kaller dem, som tar opp emner som genmanipulasjon, AIDS, anoreksi, fedme, ENØK for å nevne noen.

Museene har også mye å hente fra litteraturen innen "education", og i vårt tilfelle særlig "science education". Bevegelser som "Science, Technology and Society" forkortet som STS ${ }^{32}$, "Public Understanding of Science and Technology" forkortet som PUST og "Scientific, Technology Literacy" forkortet som STL ${ }^{33}$ setter fokus på naturvitenskapen i dagliglivet og at informasjonen må knyttes til den lærendes egen virkelighet. Informasjonen må velges med tanke på publikums behov snarere enn selve kunnskapssystemets struktur. Det betyr f.eks. at ikke alle aspekter av et fagområde kan belyses hver gang.

I det seinere har museumsfolk selv satt spørsmålstegn ved museenes nøytralitetslinje, som i sin iver for ikke å støte noen lar være (eller la oss heller si forsøker å la være) å velge side. ${ }^{34}$ En slik formidlingspolitikk har ført til at informasjonen som formidles er fokusert på faktaopplysninger i stedet for problemstillinger til ettertanke. De temaene museene har valgt har ofte vært ufarlige og lite samfunnsaktuelle, fordi samfunnsaktuelle tema kan være vanskelige å ikke ta stilling til, eller fordi de kan virke støtene i seg selv.

På museumskonferansen $N$ år tradisjonene står $i$ veien arrangert av Norsk museumsutvikling ble det diskutert at museene i større grad bør ta opp vanskelige tema, være tydeligere i sine valg og holdninger, tørre å være kontro- 
versielle framfor konvensjonelle, problematisere og nyansere mer enn å være objektive og verdinøytrale (Norsk museumsutvikling 2000). Som en oppfølger til denne konferansen har ABM-utvikling (Statens senter for arkiv, bibliotek og museum) satt i gang et prosjekt kalt "BRUDD, der man ønsker at noen museer skal bryte med "nøytralitets tradisjonen". I Sverige har de hatt gående et prosjekt som de kaller "Svåra saker" der målet blant annet er å sette fokus på emner som er vanskelige, men relevante for sin samtid (Silvèn 1998). Alle disse forsøkene blir gjort fordi man ønsker at museene skal møte publikum der de er og ta opp problemstillinger som de er opptatt av og få dem til å reflektere over sine egne holdninger og kunnskap. Slik skal museumsformidlingen gjøres mer publikumsrelevant og interessant.

\section{Kunnskap satt inn i kontekst}

Gjenstanden er det viktigste innholdet i museet. Her kan publikum ikke bare lese om den, eller se to-dimensjonale bilder av den, men virkelig oppleve gjenstanden i tre dimensjoner og i beste fall ta på den og bruke den. Museet setter gjenstanden inn i ulike kontekster alt etter hvilken museumstype det er. Det kan være en historisk kontekst, det kan være en relevant sammenheng gjenstanden opptrer i, eller et eksperiment der publikum kan bruke gjenstanden.

\section{Samarbeid med andre settinger}

Museumspedagoger kan også inngå et aktivt samarbeid med andre settinger for å formidle samme tema.

Sammarbeid mellom skole og museum er kanskje det beste eksemplet. Funn viser at museenes formidlingstilbud kan lette og bedre skolens formidling. ${ }^{35}$ Med det som utgangs- punkt utviklet vi den utvidete klasseroms modellen (Extended Classroom Model, ECM) som nevnt tidligere (Frøyland 1997, 1998). Elevene fikk undervisning i tre settinger; klasserommet, på museet og ute i naturen. Vi brukte tid på undervisningen og satte det faglige innholdet i ulike kontekster. I tillegg til det kognitive utbyttet kom det fram hvordan det å ta i bruk ulike settinger, skifte miljø, holdt motivasjonen hos elevene oppe gjennom hele undervisningsopplegget.

Chen et al. (1998) gjorde et lignende forsøk der skole, museum og elevens hjem ble brukt. Deres idé var også å gjenta kunnskapen i ulike settinger og ulike kontekster. De kaller denne type læring for resonans læring. Og igjen viste resultatene at dette gav utbytte både kognitivt og affektivt.

Når det gjelder utbyttet av samarbeid mellom andre typer læringsarenaer, gjenstår mye forskning. Det er en trend i tiden at myndighetene oppfordrer flere av de uformelle læringsarenaene som bibliotek, arkiv og museer til samarbeid. I England er sammenslåing mellom disse satt i gang, og i Norge er det utarbeidet en Stortingsmelding hvor dette aspektet blir diskutert (Kulturdepartementet 19992000). Stortingsmeldingen fokuserer først og fremst på at det vil lette en del praktisk arbeid dersom disse slås sammen. Det interessante $\mathrm{i}$ vårt tilfellet er at de tre miljøene blir sett under ett, og at myndighetene sier noe om hva de vil med disse i forhold til et samfunnsmessig behov. Det skal bli interessant å følge med framover hvilke effekter dette kan få både $\mathrm{i}$ forhold til folks oppfatning av disse miljøene, og om samarbeidet gir publikum et læringsutbytte. 


\section{De store museene kan gi mer enn det de typisk presenterer}

I de museene som er store nok, kan museumspedagogene planlegge museumsformidlingen som noe mer enn utstillinger, der det tilbys bøker, video, spill etc. som publikum kan ta med seg hjem. De kan arrangere turer ut i nærmiljøet relaterte til utstillingene, eller kurs til publikum som er relevante. Dermed bruker museet alene multiple settinger i sin formidling, og gir publikum tilbud de må tilegne seg over tid og satt inn i ulike kontekster.

Men dette er noe bare de store museene har mulighet for å gjøre. De museene som ikke kan utvidet sitt tilbud i så stor grad, kan konsentrere seg om det ingen andre settinger enn museene kan tilby, og gjøre en god jobb på det.

\section{DET UNIKE VED MUSEER SOM \\ LÆRINGSARENA}

Mange har forsøkt å si noe om det unike ved museene som læringsarena. Jeg ønsker her å sitere Sweeney og Lynds (2001):

They [informal learning environments like museums] provide the members of a community with various ways to learn about the science. Through collections, exhibitions, unique environments, and staff expertise, these institutions create powerful firsthand learning experiences that honour multiple learning styles and background.

Opportunities for general public to learn science by inquiry are rare. Passive learning opportunities are readily available. Science-related documentaries are common on cable television, computer-based science materials are widespread on the Internet, and scientific computer packages are becoming more popular. Even when this information is of high quality, it often does not have the impact and multidimensionality of tangible objects, multisensory experiences, and reality-based learning situations offered in a museum, science centre, or other ISLCs [informal science learning centres].

$\AA$ tenke at museet er én av flere læringsarenaer, gir museumspedagogene mulighet til å konsentrere seg om det unike ved museene som læringsarena. Museumspedagogene kan konsentrere innsatsen rundt det Sweeney og Lynds (2001) trekker fram som det unike ved museene, og som ingen andre settinger har. Ingen kan gjøre alt og en slik avgrensing kan være til hjelp når man skal prioritere. Slik kan også de ulike settingene utvikle seg og spesialisere seg på ulike ting, og vi som publikum eller besøkende opplever at vi făr ulike tilbud.

\section{KonkLUSJON}

Temaet her har vært museer som læringsarena, der læring blir oppfattet som en individuell prosess som skjer over tid. Jeg har framsatt et rammeverk eller en teori for museumspedagogers praksis som jeg har kalt MEMUS (multiple erfaringer i multiple settinger). Jeg har argumentert for at gjennom bruk av MEMUS kan museene

- gi publikum med ulike intelligenstyper og tilnærmingsmåter noe som passer for dem, der Gardners multiple intelligens teori er brukt som grunnlag.

- gi publikum informasjon som er relevant og interessant for dem, og sette informasjon inn $\mathrm{i}$ relevant kontekst.

- sammen med andre læringsmiljø eller settinger ta opp samme tema. På den måten får publikum presentert informasjon fra ulike vinklinger og gjennom flere settinger, ikke bare ved et kort museumsbesøk. Dermed blir det tatt hensyn til at læring skjer over tid. 


\section{Noter}

- Texten är grundad på 'artikkel 2' av författarens avhandling:

Fra grasstein til ekte sølv. En modell og et teoretisk rammeverk for hvordan museene kan bidra til a øke folks naturvitenskapelige forståelse, med geologi som eksempel.

Hovedmålet med oppgaven er å skissere hvordan museene kan bidra til å øke folks forståelse i naturvitenskap. Oppgaven består av 4 artikler som hver tar for seg problemstillinger knyttet til hovedmålet.

I artikkel 1 stilles følgende spørsmål: Bidrar museene i dag til naturvitenskapelig forståelse? Hvordan reagerer folk når de blir konfrontert med naturvitenskapelig relaterte utfordringer som f.eks. radon problematikken? Ser de på museene som steder hvor de kan innhente informasjon som kan hjelpe dem til å forholde seg til slike problem?

I artikkel 2 blir det gitt forslag til hvordan museene kan bidra gjennom praktisering av det teoretiske rammeverket multiple erfaringer i multiple settinger (MEMUS).

I artiklene 3 og 4 blir modellen, det utvidete klasserom, og utprøvingen av den presentert som et eksempel på hvordan museum og skole kan samarbeide om å bidra, basert på MEMUS.

- Den omfattande bibliografin till uppsatsen finns tillgänglig på tidskriftens hemsida www.nordiskmuseologi.com

- Jeg vil takke Ellen Karoline Henriksen og Marianne Ødegaard som har kommet med uvurderlige kommentarer. Takk også til Hans Arne Nakrem og Arne W. Martinsen for deres kommentarer.

1. Crane et al. 1994; Falk og Dierking 2000; Roshelle 1995.

2. Piaget 1970; Flavell 1963; Gruber \& Vonèche
1995; Inhelder \& Piaget 1958.

3. Vygotsky 1930, 1933, 1935/1978, 1934/2000;

Newman et al. 1986; Wertsch 1985.

4. Driver \& Easley 1978; Driver et al. 1994; Viennot 1979 .

5. Fosnot 1996; Lave \& Wegner 1991; Steffe \& Gale 1995; Wertsch 1991.

6. Good et al. 1993; Osborne 1998.

7. Brook 1994; Roper \& Davis 2000

8. Vygotsky 1978; Wertsch 1986.

9. Vygotsky 1978; Berk 1986; Wertsch 1985.

10. Bitgood \& Benefield 1989; Griggs 1983; Screven 1986; Shettel-Neeube \& O’Reilly 1981.

11. Hilke et al. 1988; Klevans 1990.

12. Mandler et al. 1980; Mandler \& Goodman 1982; Schauble et al. 1998.

13. Bruner 1996; Cortazzi 1993; Feldman et al. 1995; Roberts 1997.

14. Bailey et al. 1996; Brooks \& Vernon 1956; Melton 1936; White \& Barry 1984.

15. Duckwort et al. 1990; Sauber 1994.

16. Borun \& Miller 1980; Davidson, Heald \& Hein 1991.

17. Bitgood \& Benefield 1989; Screven 1986; Shettel-Neeube \& O'Reilly 1981.

18. Bitgood et al. 1991; Miles et al. 1982; Shettel 1976.

19. Abrams \& Falk 1995, 1996; Bielick \& Karns 1998; Falk \& Holland 1994; Falk, Luke og Abrams 1996; Holland \& Falk 1994; Luke et al. 1998; Luke et al. 1999; McKelvey et al. 1999; McManus 1993; Medved 1998; Stanton 1994; Stevenson 1992.

20. Ceci \& Roazzi 1994; Cole 1975; DeLoache \& Brown 1979; Frank 1992; Gelman 1978.

21. Hilke et al. 1988; Klevans 1990; Menninger 1991.

22. Borun et al. 1983; Friedman, Eason \& Sneider 1979.

23. Borun 1977; Brooks \& Vernon 1956; Eason \& Linn 1976; Koran et al. 1986. 
70 24. Diamond 1986; Koran \& Koran 1984; Koran et al. 1986, Koran et al. 1988.

25. Ellis 1993; Koran \& Koran 1996

26. Rubin 1980; Saltz \& Saltz 1986.

27. Hilke et al. 1988; Klevans 1990; Menninger 1991.

28. Se bl.a. Falk \& Dierking 1995; Hein 1998.

29. Brown \& Ferrara 1985; Matusov \& Rogoff 1995.

30. Crane et al. 1994; Falk \& Dierking 2000; Roshelle 1995.

31. Aikenhead 1994; Jenkins 1994; Layton et al. 1993.

32. Aikenhead 1994; Solomon \& Aikenhead 1994.

33. Coborn 1996; Jenkins 1994; Layton et al. 1993; Shamos 1995.

34. Norsk museumsutvikling 2000; Journal of Museum Education 1998.

35. Allard et al. 1994; Anderson 1999; Gardner 1993b; Sheppard 1993

\section{Summary}

Museum pedagogics and the theory of multiple intelligences,

The paper proposes a theoretical framework for how museums might contribute to improving the public understanding of science. The theory suggests that multiple experiences, based on the concept of multiple intelligences in multiple settings (MEMUS), increase the possibility of achieving understanding in a variety of areas. MEMUS includes two perspectives on learning: first that learning is an individual process and second that learning is a process over time. These two perspectives should affect the way museums organise their exhibitions, educational programmes etc, and the topics they choose to present to their visitors. Examples, based on recent international museum studies, are given of how museums can provide their vistitors with multiple experiences.

\author{
Radgiver Merethe Frøyland \\ doktorgrad i museumsformidling \\ Adr. ABM-utvikling \\ postboks 8145 Dep, 0033 Oslo, Norge \\ Tel. +4723117500 , \\ Faks. +4723117501 \\ E-mail:merethe.froyland@abm-utvikling.no
}

